九州大学学術情報リポジトリ

Kyushu University Institutional Repository

\title{
Study on Profitability and Factors Influencing Participation in Organic Farmer Association : A Case Study of Sangthong District, Vientiane Capital, Laos
}

Phranakhone, Pangna

Department of Planning and Cooperation, Ministry of Agriculture and Forestry of Laos

Nanseki, Teruaki

Laboratory of Agricultural and Farm Management, Division of Agricultural and Resource

Economics, Department of Agricultural and Resource Economics, Faculty of Agriculture, Kyushu University : Professor

https://doi.org/10.5109/1526318

出版情報: 九州大学大学院農学研究院紀要. 60 (1)，pp.259-264，2015-02-27. Faculty of Agriculture, Kyushu University

バージョン :

権利関係 : 


\title{
Study on Profitability and Factors Influencing Participation in Organic Farmer Association: A Case Study of Sangthong District, Vientiane Capital, Laos
}

\section{Pangna PHRANAKHONE ${ }^{1}$ and Teruaki NANSEKI ${ }^{2 *}$}

\author{
Laboratory of Agricultural and Farm Management, Division of Agricultural and Resource Economics, \\ Department of Agricultural and Resource Economics, Faculty of Agriculture, \\ Kyushu University, Fukuoka 812-8581, Japan \\ (Received October 31, 2014 and accepted November 14, 2014)
}

\begin{abstract}
This study compared profitability between the farmers participating in Sangthong Organic Farmers Association (SOFA) and the inorganic farmers in Sangthong District, Vientiane Capital, Laos, and estimated the factors influencing farmers to participate in the SOFA. The data collection was conducted with random sampling procedure to 110 organic farmers and 110 inorganic farmers in 10 target villages. Comparative analysis on revenue structure was conducted, to investigate whether organic farmers could gain more profit from rice production than inorganic farmers. Binary logistic regression model was employed to identify the factors influencing farmers' participation in the SOFA. The results of revenue structure comparison showed that as hypothesized, the organic farmers can get higher profit from their rice than the inorganic farmers. Binary logistic regression analysis showed that six factors influencing farmers' participation in the SOFA, including their age, farming experiences, family labors, farming activities, education and profit margin. This study implied the government to promote local organic aroma rice to more private export companies; the local authority can encourage local farmers to participate in organic group, by providing more information and simplifying some processes; the private companies should maintain reasonable price to sustain profits for organic members.
\end{abstract}

Key words: Hom Sangthong Aroma Glutinous Rice, Laos, Sangthong District, Sangthong Organic Farmer Association (SOFA), Vientiane

\section{INTRODUCTION}

Traditionally, rice producers in Sangthong District are using limited amount of chemical inputs including fertilizers, herbicides and insecticides. Most of them are not using any of them. In fact, the local farmers are producing with traditional techniques which are already closed to organic technique. In 2006, the Project for Promotion of Organic Rice in Lao PDR (ProRice I) had been introduced to Sangthong District with the aims to promote organic production (green agriculture) and provide markets, it is also to promote local aroma glutinous rice, "Hom Sangthong", and some local varieties. Within 22 months of the ProRice period, organic farmers could improve their incomes from rice production by selling their rice with higher price to the processing companies and millers. Regarding the success of ProRice Phase I, the continuous project called Project for Promotion of Organic Farming and Marketing in Laos (ProFiL) or ProRice Phase II had been continuously implemented in Sangthong District and expanded the project sites to other northern provinces. The Phase II was lasted in 2009 to 2011, when the number of permanent organic members was 538 and organic area was 870 ha in Sangthong District.

After the project ended, private companies had become main investors for organic aroma rice production, and the processes had been improved to control quality

\footnotetext{
${ }^{1}$ Department of Planning and Cooperation, Ministry of Agriculture and Forestry of Laos

2 Faculty of Agriculture, Kyushu University

* Corresponding author (E-mail: nanseki@agr.kyushu-u.ac.jp)
}

of the products. Many farmers had to cancel their organic member status due to required qualifications of the SOFA, thus number of the organic members had reduced rapidly to 225 , with organic area of 266 hectares. Therefore, this study aims to find out the suitable implications for concerned authorities to persuade local farmers to participate in the association. The objectives of the study include: firstly, to examine profitability of organic and inorganic rice production with its hypothesis of, "Organic farmers could gain higher profit than non-organic farmers"; secondly, to identify factors influencing participation of local farmers into the SOFA.

\section{METHODOLOGY}

Sangthong District was established on November 13, 1993, as one district of Vientiane Capital composing with nine districts. It locates 55 kilometers to the northwest of the City of Vientiane. The total area is 800 sq. kilometers or 80,000 hectares, and the agricultural areas cover 38,673 hectares $(48.34 \%)$, the forest area and national park cover 41,117 hectares $(51,40 \%)$, and the urbanized area cover 270 ha $(0.26 \%)$. The District Center of Sangthong is called "Phialad", the small developing town along the national route No. 11 . This district is composed with 5 village clusters, containing 37 villages, within which 10 villages have been involved in the organic rice production.

\section{Data Collections}

Data used in this study is collected by a field survey at 10 organic villages, i.e., Taohai, Hai Neua, Nahoypang, 
Nalad, Namieng, Nathiem, Nasaonang, Natan, Pakthep and Hai Tai, of Sangthong District, Vientiane Capital of Laos. Two questionnaires were used in this survey: Questionnaire 1 was for the organic respondents, and Questionnaire 2 was for the inorganic respondents. There were 2 main parts: questions for general and socioeconomic information, and questions for the rice production conditions. Altogether 220 respondents were interviewed, with 110 of them were organic farmers and other 110 were inorganic farmers. In addition, data about the price of goods, rental fees and wages was collected as well, from the local and central market in Vientiane City.

\section{Data Analysis}

Objective 1: To examine profitability

Descriptive analysis is used to analyze the demographical and socio-economic data of the respondents. To describe comparatively between organic and inorganic respondents, the $\mathrm{T}$ Statistic Analysis was applied by using the mean values and standard deviation values to estimate. The operation is carried out by the software of Stata Ver.16.0

Total Revenue Estimation: Total Revenue per ha of Organic and Inorganic Rice Production is defined by the equation:

$$
\boldsymbol{T R}=\boldsymbol{Y} \times \boldsymbol{U p}
$$

where, $T R=$ Total Revenue per ha (K/ha)

$Y=$ Yield of organic and inorganic rice ( $\mathrm{kg} / \mathrm{ha})$

$U p=$ Unit price of organic and inorganic rice ( $\mathrm{K} / \mathrm{kg})$

Production Costs Estimation: Production Costs per ha of Organic and Inorganic Rice Production is defined by the equation:

$$
T C=V C+F C
$$

where, $T C=$ Total Production Costs (K/ha)

$V C=$ Variable Costs (K/ha, Seed, Manure, Bio-extract, Chemical Fertilizer, Herbicide, Pesticide, Transportation, Fuel, Labors)

$F C=$ Fixed Costs (K/ha, Machineries, Rental Land, Irrigation)

Gross Margin Estimation: Gross Margin per ha is the rest of Total Revenue after put out total variable costs

$$
G M=T R-V C
$$

where, $G M=$ Gross Margin (K/ha)

$T R=$ Total Revenue $(\mathrm{K} / \mathrm{ha})$

$V C=$ Total Variable Costs (K/ha)

Profit Estimation: Profit per ha is definitely a real gains after subtracting every items of production costs (both variable costs and fixed costs).

$$
P F=T R-T C
$$

where, $P F=$ Profit (K/ha)

$T R=$ Total Revenue $(\mathrm{K} / \mathrm{ha})$

$T C=$ Total Production Costs $(\mathrm{K} / \mathrm{ha})$

To estimate profit margin gained from organic and inorganic rice in this research, all items in production cost would be included, both variable costs and fixed costs. The production costs have been estimated by including all payments, whereof direct payment- is the money paid actually for farming inputs and/or hiring; and indirect payment- is the cost of their own properties that they did not have to pay.

To identify the factors influencing farmers to participate in the SOFA (Objective 2),

The selected model to carry out the accomplishment of the second objective is Binary Logistic Regression Model, the logistic equation is as fellow:

$$
\begin{aligned}
\boldsymbol{Y}= & \boldsymbol{\beta}_{0}+\boldsymbol{\beta}_{1} \boldsymbol{X}_{1}+\boldsymbol{\beta}_{2} \boldsymbol{X}_{2}+\boldsymbol{\beta}_{3} \boldsymbol{X}_{3}+\boldsymbol{\beta}_{4} \boldsymbol{X}_{4}+\boldsymbol{\beta}_{5} \boldsymbol{X}_{5}+\boldsymbol{\beta}_{6} \boldsymbol{X}_{6} \\
& +\boldsymbol{\beta}_{7} \boldsymbol{X}_{7}+\varepsilon
\end{aligned}
$$

where, $Y=$ Dependent Variable (Dummy)

$\beta_{0}=$ Intercept

$\beta_{i}=$ Estimated Coefficients $(i=1$ to 7$)$

$X_{i}=$ Independent Variables ( $i=1$ to 7 )

$\varepsilon=$ Error Term

There are 7 independent variables, thus: (i) $X_{1}$ : Age of household head; (ii) $X_{2}$ : Experiences on rice farming of the household head; (iii) $X_{3}$ : Education of the household head; (iv) $X_{4}$ : Family available labors; (v) $X_{5}$ : Total rice product; (vi) $X_{6}$ : Profit per hectare; and (vii) $X_{7}$ : Farming activities or fields utilization pattern. The dependent variable is dummy, where 1 representing for the farmers those participated in the SOFA, and 0 representing for the non-participating farmers.

\section{RESULTS AND DISCUSSION}

Table 1 provides the information of demographical, socioeconomic and production inputs of both organic and inorganic respondents, sourced from the conducted survey in 2012. In this term, the mean and standard deviations of the values of each variable have been used and compared with the T Statistic Value. There are five (5) strongly significant variables regarding household heads' experiences, family size, family labors, total product and product price. The other fellow significant variables are household heads' age, land holding size (land tenure), rice field size, yield and bio-extract. Further details have been described below:

(1) Household heads' experiences (years) is the period/duration of rice farming, it shows the positive relationship and strong significance on T Statistic Analysis (6.82***), this means the organic respondents practice their rice farming in the longer periods, or have higher experiences on rice farming, than inorganic respondents. The mean value can visualize the difference, since organic respondents experiencing 32.60 years which is nearly ten years longer than inorganic respondents who practice for 22.82 years on average. (2) Family size (persons) is the total family members presenting in the family list as on the time of survey conducted. It gets positive relationship and strongly significant at the value of $4.16 * * *$ on T Statistic Analysis, means the organic members' families (5.36) are larger than inorganic respondents (4.55). (3) Family labors (persons) is the available labors working for rice farming in the family. The comparative relationship is positive and strongly significant at $13.12^{* * *}$, 
Table 1. Demographical Characteristics of Organic and Inorganic Respondents

\begin{tabular}{|c|c|c|c|c|c|c|c|}
\hline \multirow{2}{*}{ Variables } & \multicolumn{3}{|c|}{ ORGANIC } & \multicolumn{3}{|c|}{ INORGANIC } & \multirow{2}{*}{ T-Stat } \\
\hline & $\mathrm{N}$ & Mean & SD & $\mathrm{N}$ & Mean & SD & \\
\hline HH Age (years) & 110 & 47.60 & 9.41 & 110 & 44.96 & 11.93 & $1.82^{* *}$ \\
\hline HH Experiences (years) & 110 & 32.60 & 9.41 & 110 & 22.82 & 11.73 & $6.82^{* * *}$ \\
\hline HH Education (years) & 110 & 9.21 & 3.95 & 110 & 8.76 & 5.64 & 0.68 \\
\hline Family size (persons) & 110 & 5.36 & 1.54 & 110 & 4.55 & 1.34 & $4.16^{* * *}$ \\
\hline Family labor (persons) & 110 & 4.43 & 1.36 & 110 & 2.45 & 0.81 & $13.12^{* * *}$ \\
\hline Land holding size (ha) & 110 & 6.12 & 4.80 & 110 & 4.64 & 5.40 & $2.15^{* *}$ \\
\hline Rice field size (ha) & 110 & 1.84 & 1.39 & 110 & 1.55 & 1.41 & $1.54^{*}$ \\
\hline Yield (Ton/ha) & 110 & 3.36 & 1.27 & 110 & 3.16 & 1.32 & 1.170 \\
\hline Total product (Tons) & 110 & 5.65 & 4.15 & 110 & 4.11 & 3.13 & $3.10 * * *$ \\
\hline Product price $(\mathrm{K} / \mathrm{kg})$ & 110 & $2,447.27$ & 104.67 & 110 & $2,171.36$ & 74.64 & $22.51 * * *$ \\
\hline Dose of usage: Seed (kg/ha) & 110 & 95.48 & 51.85 & 110 & 101.31 & 60.93 & -0.76 \\
\hline Dose of usage: Manure (kg/ha) & 110 & 266.14 & 503.64 & 110 & 165.61 & 696.94 & 1.23 \\
\hline Dose of usage: Bio-extract (kg/ha) & 110 & 1.27 & 9.41 & 110 & 0.00 & 0.00 & $1.42^{*}$ \\
\hline Dose of usage: Fertilizer (kg/ha) & 110 & 0.00 & 0.00 & 110 & 3.88 & 19.74 & -2.06 \\
\hline Dose of usage: Herbicide (kg/ha) & 110 & 0.00 & 0.00 & 110 & 0.00 & 0.00 & 0.00 \\
\hline Dose of usage: Pesticide (kg/ha) & 110 & 0.00 & 0.00 & 110 & 2.62 & 9.10 & -3.02 \\
\hline
\end{tabular}

Source: Survey data, 2012

Notes: *** and *** denote being statistically significant at the level of $10 \%, 5 \%$ and $1 \%$, respectively

which indicate that the number of available labors in organic families (4.43 persons) is averagely higher than inorganic families (2.45 persons). (4) Total product (tons) is the total rice products in the total rice field areas. The product gets positive relationship and strong significance ( $\left.3.10^{* * *}\right)$, it shows that the organic farmers achieved higher total product after comparing the mean value of 5.65 tons with 4.11 tons achieved by inorganic farmers. (5) Product price $(\mathrm{K} / \mathrm{kg}$ ) is the unit product price. The prices between organic and inorganic rice product are different as it shows that price of organic rice $(2,447.27 \mathrm{~K} / \mathrm{ha})$ is more expensive than inorganic $(2,171.36 \mathrm{~K} / \mathrm{ha})$. (6) Household heads' age (years) is the current age of the family heads working for rice production. This variable is significant and gets positive relationship, means the organic farmers are seemly older than inorganic farmers but not so different in the means of 47.60 and 44.96 years old. (7) Land holding size (ha) is the total agricultural land of farmers, and rice field size (ha) is the total paddy fields. Both of them are significant variables with positive relationship, it indicates that the organic farmers holding larger agricultural land, and/ or larger paddy fields than inorganic farmers. (8) Bioextract ( $\mathrm{kg} / \mathrm{ha}$ ) is the organic element functioning as biofertilizer and bio-pesticide. It's significant with positive relationship, this is already agreed that the users are only some organic farmers since the mean value of inorganic is zero (0) kg/ha. (9) There are several variables that are not significant and negative relationships regarding seed (kg/ha), chemical fertilizer ( $\mathrm{kg} / \mathrm{ha})$ and pesticide $(\mathrm{kg} / \mathrm{ha})$.

\section{Comparative Analysis of Revenue Structure}

In Table 2, the comparative results of production costs of organic and inorganic rice farming are described. The $\mathrm{T}$ Statistic Value shows that there are 4 significant and positive-relationship variables on the variable costs and 1 on the fixed costs, thus: (1) Bio-extract (a.3)- this means that only organic farmers have used this input for their rice more. (2) Transportation ( $a .7$ ) and Fuel (a.8)- this states that organic farmers spent on transportation and fuel more than inorganic since they used their own vehicles more, as well as their own machines on land preparation and weeding. (3) Owned machineries (b.1.1) - the mean value is higher on organic side, this means organic farmers indirectly spent more for their machineries, on the other hand, inorganic farmers had to spent on hiring the machines more than organic respondents.

The comparison results to achieve the objective 1 and its hypothesis are showed in Table 3. Organic farmers could meet higher outputs than inorganic farmers according to the $\mathrm{T}$ Test value of the total revenue which is strongly significant and has positive relationship. On the gross margin comparison, it states that the mean of gross margin gained by organic farmers is better than inorganic farmers respectively. Regarding profit, the organic respondents could achieve the higher profit from their rice production than inorganic respondents.

\section{Binary Logistic Regression Analysis}

Binary Logistic Regression Analysis of the surveyed data has identified 6 factors influencing the farmers' participation in the Sangthong Organic Farmers Association 
Table 2. Production Costs Analysis (K/ha)

\begin{tabular}{|c|c|c|c|c|c|c|c|}
\hline \multirow{2}{*}{ Items } & \multicolumn{3}{|c|}{ ORGANIC } & \multicolumn{3}{|c|}{ INORGANIC } & \multirow{2}{*}{ T-Stat } \\
\hline & $\mathbf{N}$ & Mean & SD & $\mathbf{N}$ & Mean & SD & \\
\hline Variable Costs & 110 & $3,418,403$ & $1,734,718$ & 110 & $3,213,157$ & $1,805,084$ & 1.25 \\
\hline a. 1. Seed & 110 & 236,096 & 129,541 & 110 & 242,129 & 148,179 & -0.32 \\
\hline a. 2. Manure & 110 & 266,135 & 503,637 & 110 & 165,606 & 696,940 & 1.23 \\
\hline a. 3. Bio-extract & 110 & 2,535 & 18,815 & 110 & 0 & 0 & $1.41^{*}$ \\
\hline a. 4. Fertilizer & 110 & 0 & 0 & 110 & 13,576 & 69,089 & -2.06 \\
\hline a. 5. Herbicide & 110 & 0 & 0 & 110 & 1,952 & 14,284 & -1.43 \\
\hline a. 6. Pesticide & 110 & 0 & 0 & 110 & 9,170 & 31,859 & -3.01 \\
\hline a. 7. 1. Owned Transport & 110 & 682 & 2,030 & 110 & 305 & 1,397 & $1.60^{*}$ \\
\hline a. 7. 2. Hired Transport & 110 & 353,500 & 214,052 & 110 & 291,594 & 183,627 & $2.30 * *$ \\
\hline a. 8. Fuel & 110 & 342,587 & 284,239 & 110 & 246,276 & 243,431 & $2.70^{* * * *}$ \\
\hline a. 9. 1. Family Labor & 110 & $1,766,661$ & $1,301,793$ & 110 & $1,639,286$ & $1,062,791$ & 0.79 \\
\hline a. 9. 2. Hired Labor & 110 & 790,331 & 571,540 & 110 & 849,540 & 853,190 & -0.6 \\
\hline Fixed Costs & 110 & $1,854,263$ & $1,213,791$ & 110 & $1,712,250$ & 947,627 & 0.97 \\
\hline b. 1. 1. Owned Machine & 110 & 690,438 & $1,053,630$ & 110 & 507,886 & 837,860 & $1.42^{*}$ \\
\hline b. 1. 2. Hired Machine & 110 & 663,825 & 799,452 & 110 & 704,364 & 628,814 & -0.42 \\
\hline b. 2. Land Fee & 110 & 500,000 & 0 & 110 & 500,000 & 0 & 0 \\
\hline b. 3. Water & 110 & 0 & 0 & 110 & 0 & 0 & 0 \\
\hline Total Prod. Costs & 110 & $\underline{\mathbf{5 , 2 7 2 , 6 6 6}}$ & $\underline{2,600,381}$ & 110 & $\underline{4,925,407}$ & $\underline{2,445,312}$ & $\underline{1.29 *}$ \\
\hline
\end{tabular}

Remark: K = Lao Kip (Local Currency: 7,996.37K = 1USD in Dec. 2012)

Source: Survey data, 2012

Notes: *** and $* * *$ denote being statistically significant at the level of $10 \%, 5 \%$ and $1 \%$, respectively

Table 3. Revenue Structure of Organic and Inorganic Respondents (K/ha)

\begin{tabular}{|c|c|c|c|c|c|c|c|}
\hline \multirow{2}{*}{ Items } & \multicolumn{3}{|c|}{ ORGANIC } & \multicolumn{3}{|c|}{ INORGANIC } & \multirow{2}{*}{ T-Stat } \\
\hline & $\mathrm{N}$ & Mean & $\mathrm{SD}$ & $\mathrm{N}$ & Mean & SD & \\
\hline Total Revenue & 110 & $8,245,771$ & $3,176,729$ & 110 & $6,844,758$ & $2,834,291$ & $3.45 * * *$ \\
\hline Gross Margin & 110 & $4,827,368$ & $2,262,227$ & 110 & $3,631,601$ & $2,130,141$ & $4.04 * * *$ \\
\hline Profit & 110 & $2,973,105$ & $2,161,267$ & 110 & $1,919,351$ & $2,341,747$ & $3,47^{* * *}$ \\
\hline
\end{tabular}

Remark: K = Lao Kip $(7,996.37 \mathrm{~K}=1 \mathrm{USD}$ in Dec. 2012)

Source: Survey data, 2012

Notes: ***denotes being statistically significant at the level of $1 \%$

Table 4. Results of Binary Logistic Regression Analysis

\begin{tabular}{|c|c|c|c|c|c|c|}
\hline & B & S. E. & Wald & $\mathrm{df}$ & Sig. & $\operatorname{Exp}(B)$ \\
\hline$X_{1}: \mathrm{AGE}$ & -0.889 & 0.217 & 16.813 & 1 & $0.000 * * *$ & 0.411 \\
\hline$X_{2}:$ EXPER & 0.976 & 0.228 & 18.263 & 1 & $0.000 * * *$ & 2.653 \\
\hline$X_{3}:$ EDUCA & 0.155 & 0.072 & 4.612 & 1 & $0.032 * *$ & 1.167 \\
\hline$X_{4}: \mathrm{LABOR}$ & 1.972 & 0.419 & 22.146 & 1 & $0.000 * * *$ & 7.182 \\
\hline$X_{5}:$ PRODU & -0.099 & 0.140 & 0.498 & 1 & 0.481 & 0.906 \\
\hline$X_{6}:$ PROFI & 0.439 & 0.186 & 5.548 & 1 & $0.019^{* *}$ & 1.551 \\
\hline$X_{7}: \mathrm{ACTIV}$ & 3.108 & 0.772 & 16.205 & 1 & $0.000 * * *$ & 22.376 \\
\hline Constant & 1.627 & 2.948 & 0.305 & 1 & 0.581 & 5.090 \\
\hline \multicolumn{7}{|c|}{ Sample size: 220} \\
\hline
\end{tabular}


(SOFA or Organic Rice Producing Group) regarding Age of household head ( $X_{1}$ : AGE), Experiences on rice farming of household head ( $X_{2}$ : EXPER), Family available labors $\left(X_{4}\right.$ : LABOR), Farming Activities ( $X_{7}$ : ACTIV), Education of household head $\left(X_{3}\right.$ : EDUCA) and Profit gained from selling rice product in 1 hectare $\left(X_{6}\right.$ : PROFI). There are 4 factors are significant at 1 percent level, and 2 factors are significant at 5 percent level. The significant factors are described as below (Table 4):

(1) Age of household head ( $X_{1}$ : AGE) is significant at 1 percent level with negative relationship to the dependent variable, this means the older farmers did not participate in the SOFA. Since the current situation of the SOFA is difficult or complicated for the older farmers, including the strict regulations, member selection process, organic techniques adaption, standard testing, etc. (2) Experiences on rice farming of household head $\left(X_{2}\right.$ : EXPER) is significant at 1 percent level with positive relationship to the dependent variable, this indicates that the farmers with high experiences on rice farming DID participate in the SOFA. As an observation, even the mean of the age of organic farmers is seemly higher or older, at the same time, the mean of experiences is much longer more than inorganic farmers. The highly experienced farmers can simply adapt to new knowledge or organic technique, and manage their organic rice fields with better practice. (3) Family available labors $\left(X_{4}\right.$ : LABOR) is significant at 1 percent level with positive relationship to the dependent variable, this shows that the farmers with more available family labors participated in the SOFA. On the demographical data, the mean of family labors of organic farmers is higher than inorganic family. With the hard works in organic fields, it seeks for many labors since most of the process in organic fields should be carried out with hands. Moreover, many family labors working in the fields can save the payment on labors hiring. (4) Farming Activities ( $X_{7}$ : ACTIV) is significant at 1 percent level with positive relationship to the dependent variable, this means the farmers utilizing their fields for only rice farming, or farmers with singlefarming activity, participated in the SOFA. Since organic rice farming needs to be protected from the risks or the waste of other cropping that may cause negative impact to the organic standard testing, e.g. the residual waste or chemical contaminants. Additionally, the regulations of SOFA state that the organic fields should be used for only organic or non-chemical practice. Indeed, in order to prevent the mentioned impact, most of organic farmers utilize their fields for only rice production.

Education of household head $\left(X_{3}\right.$ : EDUCA) is significant at 5 percent level with positive relationship to the dependent variable. It states that the farmers with higher education mostly participated in the SOFA, since educated farmers may be able to learn new technique faster, especially on organic technique that they have to estimate the quantity of manure use, payments, and field operations to achieve the organic standard. (6) Profit gained from selling rice product per hectare $\left(X_{6}\right.$ : PROFI) is significant at 5 percent level with positive relationship with the dependent variable. This already certifies that the high profit from selling rice with higher farm-gate price is attractive for the farmers to participate in the group.

\section{CONCLUSION AND POLICY IMPLICATIONS}

\section{Conclusion}

In term of production costs analysis, all the payments (direct and indirect payments) have been included in order to estimate the profit, so that the production cost of organic farmers is a little bit higher than inorganic, but not so different on average. In fact, the farmers in Sangthong District still maintain their traditional production techniques which are close to organic ones, therefore, the inorganic respondents do not even use much chemical contaminants. At the same time, both of them also use manure that can be found easily from their livestock, agricultural waste, food waste, local knowledge on bio-fermented fertilizer, etc.

Regarding the results of comparative analysis of revenue structure, to examine the profit and gross margin of organic and inorganic respondents, it has indicated that organic farmers can make higher profit and gross margin in one hectare. This means, the hypothesis of the objective 1 is acceptable.

The result of binary logistic regression has found 6 factors strongly influencing the participation in the organic association, including age, experiences, family available labors, farming activities, education, and profit. These indicate that the farmers with longer experience on rice farming, more labors in the family, only-rice growing, educated, would have participated in the association. Additionally, the higher farm-gate price of organic rice has also been motivating the farmers to become members of the SOFA.

To sum up, the organic respondents can meet higher gross margin and profit on average because they can sell their high quality rice product with higher price than other ordinary/inorganic rice. On the other hand, the organic farmers have to work harder and carefully to achieve the organic standard since the examining from the ICS is the main challenge for them. Indeed, to be the members of the organic rice producing group (SOFA) can maintain and promote the local traditional rice varieties, and improve the family income from rice production.

\section{Policy recommendations}

According to the results of survey and the foregoing empirical analyses, policy recommendations to the authorities can be put forward as below: (1) The Government of Laos represented by the Department of Agriculture under the Ministry of Agriculture and Forestry (MAF) and the Agricultural and Forestry Office of Vientiane Capital (Vientiane CAFO) should promote the traditional rice varieties of Sangthong District to more private export companies, thus expanding the market and strengthen the organic farmers association, which can promote the organic rice production in Sangthong District to meet sustainability. (2) In order to maintain high profit for the organic members, the private investing companies and millers should buy the organic rice products with reason- 
able farm-gate price, as well as providing facilities for production process and quality control, and conducting trainings or exchange visits for them. (3) To expand the organic producing group, the Sangthong District Agricultural and Forestry Office (Sangthong DAFO) represented by the Sangthong Organic Farmers Association (SOFA) should encourage the local farmers to participate in Organic Producing Group by providing information on advantages of organics and memberships, and simplifying documentation and member selection process. (4) To increase the total product and improve the yields, the organic farmers should strictly practice the organic technique, following the regulations of the SOFA, and utilize the bio-extract more on making green fertilizers and controlling pests, and keep their soil fertile simultaneously.

\section{ACKNOWLEDGEMENTS}

The authors would like to thank Dr. Dongpo LI, Kyushu University, for his kind support in preparing this paper.

\section{REFERENCES}

Asian Network for Sustainable Organic Farming Technology, ANSOFT/AFACI 2010 Country Report on Organic Agriculture in Lao PDR

Department of Agriculture, MAF and Helvetas Laos 2008 Midterm Evaluation Report of Project for Promotion of Organic Rice (ProRice) in Sangthong District, Vientiane Capital, Lao PDR

Department of Agriculture, MAF and Helvetas Laos 2009 Project Document of Project for Promotion of Organic Rice in Lao
PDR, Phase II . 2009-2011

Department of Agriculture, MAF and Helvetas Laos 2010 Annual Report of Project for Promotion of Organic Rice and Marketing in Lao PDR (ProFil, Phase II)

FAO COAG 2003 Good Agriculture Practices. Source: http:// www.fao.org/prods/gap/

Foldvary, F. 2012 What is profit? Freeman, 62: 33. Retrieved from http://search.proquest.com/docview/1189700199?accoun tid=27835

Gelar Satya Budhi 2006 Factors influencing Payment of Irrigation Service Fee. J. Humaniora, 10.1: 8-14

Karl L. Wuensch 2009 Binary Logistic Regression with PASW/ SPSS

Latmany Phonesavanh 2008 Agricultural Mechanization in Rural Area of Lao PDR: A Case Study of Farm Tractorization. Kyushu University (Japan), pp. 55-65.

Ministry of Agriculture and Forestry (MAF) of Lao PDR 2005 Lao Organic Standard. Issued No. 1666, pp. 1-27

Nem Nei Lhing 2009 An Impact Assessment of the Performance of PACT Microfinance Program on Rural Households: A Case Study of Dry-zone Area, Central Myanmar. Kyushu University (Japan), pp. 64-73

Sangthong District 2010 Socio-economic Development Plan (2011-2015) of Sangthong District, Vientiane Capital, Lao PDR

S. Mohammed 2011 Economics of Rainfed and Irrigated Rice under Upper Benue River Basin Gombe State, Nigeria. Cont. J. Agricultural Economics 5, No. 2141-4130, 1: 14-22

Sydney C. James and Phillip R. Eberle 2000 Economic and Business Principles in Farm Planning and Production. Iowa State University Press, pp. 33-34

William H. Greene 2008 Econometric Analysis. Sixth Edition, New York University

Zikrullah Safi, Luc Hippolyte and Andreas Buerkert 2011 Economic Analysis of Cereal, Vegetable and Grape Production Systems in Urban and Peri-urban Agriculture of Kabul, Afghanistan. Cambridge University Press, Expl. Agric., 47 705-716 